\title{
Picture Stories
}

\section{A case of human tail syndrome with spinal dysraphism}

\author{
*Amol Ramesh Nage ${ }^{1}$, Pradnya Suhas Bendre ${ }^{1}$, Flavia D'souza ${ }^{1}$, Nitin Palse $^{1}$
}

Sri Lanka Journal of Child Health, 2017; 46(1): 91-92

DOI: http://dx.doi.org/10.4038/sljch.v46i1.8230

(Key words: Human tail, dysraphism)

\section{Introduction}

A true or persistent vestigial human tail arises from the most distal remnant of the embryonic tail, is covered by skin and contains adipose tissue, connective tissue, muscle, blood vessels and nerves but no bone, cartilage, notochord or spinal cord ${ }^{1}$. It arises by retention of structures normally found in fetal development and is easily removed surgically, without residual effects ${ }^{1}$. Pseudotail is a lesion with a lumbosacral protrusion and a superficial resemblance to a true tail, for e.g. anomalous prolongation of coccygeal vertebrae, lipoma or teratoma ${ }^{1}$. We report a child with a tail-like caudal appendage that had been present since birth.

\section{Case report}

A healthy 17 day old neonate was brought for investigation of a tail-like structure that had been present in the lumbosacral area since birth (see Figure 1).

On physical examination, the appendage was taillike, soft, well circumscribed, $10 \mathrm{~cm}$ long and $3 \mathrm{~cm}$ thick. It was located on a soft disc like lipoma and was soft, non-tender and covered with normal skin. There was no voluntary movement in the tail. No significant findings were noted in general and systemic examination. Child had no other congenital defects. The possibility of a true neonatal tail as opposed to a pseudotail was considered. Magnetic resonance imaging (MRI) of the spine showed spina bifida in the lumbosacral area (Figure 2).

\section{${ }^{1}$ Bai Jerbai Wadia Hospital for Children, India \\ *Correspondence: dr_amolnage@yahoo.co.in}

(Received on 15 February 2016: Accepted after revision on 22 April 2016)

The authors declare that there are no conflicts of interest

Personal funding was used for this project.

Open Access Article published under the Creative

Commons Attribution CC-BY License.

Excision of tail was done. The post-operative specimen is shown in Figure 3. Histopathological examination revealed that the tail-like structure contained skin, muscle and adipose tissue only. Baby recovered uneventfully and no neurological deficit was evident on follow-up until 12 months of age.

\section{Discussion}

In our patient the histopathology of the excised tail revealed skin, muscle and adipose tissue but no bone, cartilage, notochord or spinal cord, making it probable that it was a true human tail. The true tail may be as long as $13 \mathrm{~cm}$ and can move and contract $^{1}$. In our patient the tail was $10 \mathrm{~cm}$ long and there was no voluntary movement of the tail. The absence of nerves on histopathology may account for the absence of voluntary movement in the tail of our patient. The human tail is often associated with occult spinal dysraphism ${ }^{2}$. In our patient, MRI of the spine showed spina bifida in the lumbosacral area. The presence of a tail-like appendage in the lumbosacral region should alert the clinician to the possibility of underlying spinal dysraphism ${ }^{2,3}$.

\section{References}

1. Dao AH, Netsky MG. Human tails and pseudo tails. Human Pathology 1984; 15(5):449-53.

http://dx.doi.org/10.1016/S00468177(84)8 0079-9

2. Singh DK, Kumar B, Sinha VD, Bagaria HR. The human tail: A rare lesion with occult spinal dysraphism- A case report. Journal of Pediatric Surgery 2008; 43:E41-3.

http://dx.doi.org/10.1016/j.jpedsurg.2008. 04.030

PMid: 18778987

3. Belzberg AJ, Myles ST, Trevenen CL. The human tail and spinal dysraphism. Journal of Pediatric Surgery 1991; 26(10): 1243-5. http://dx.doi.org/10.1016/j.jpedsurg.2008. 04.030

PMid: 18778987 


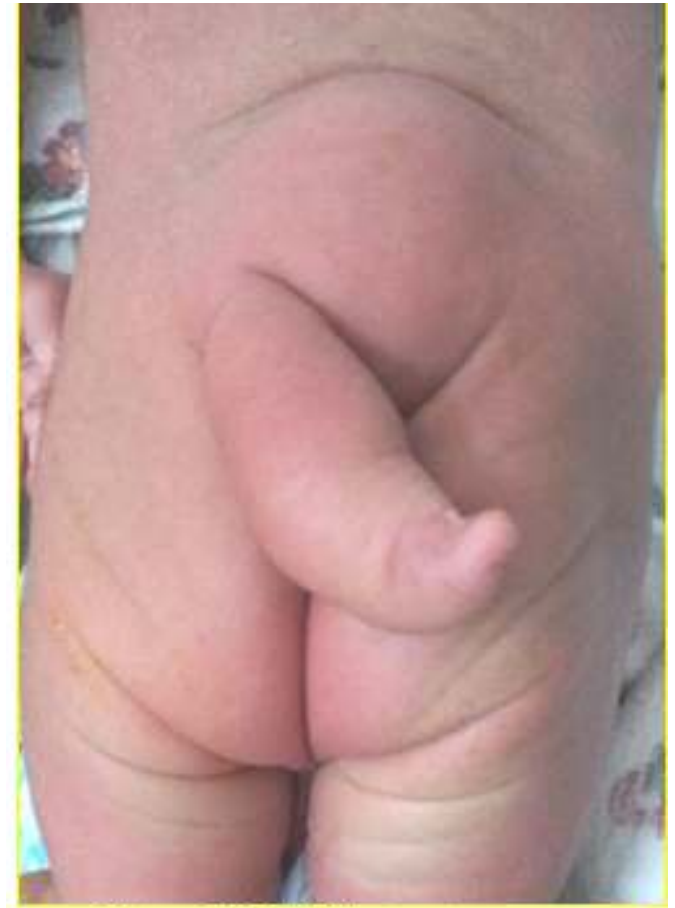

Figure 1: Tail-like structure

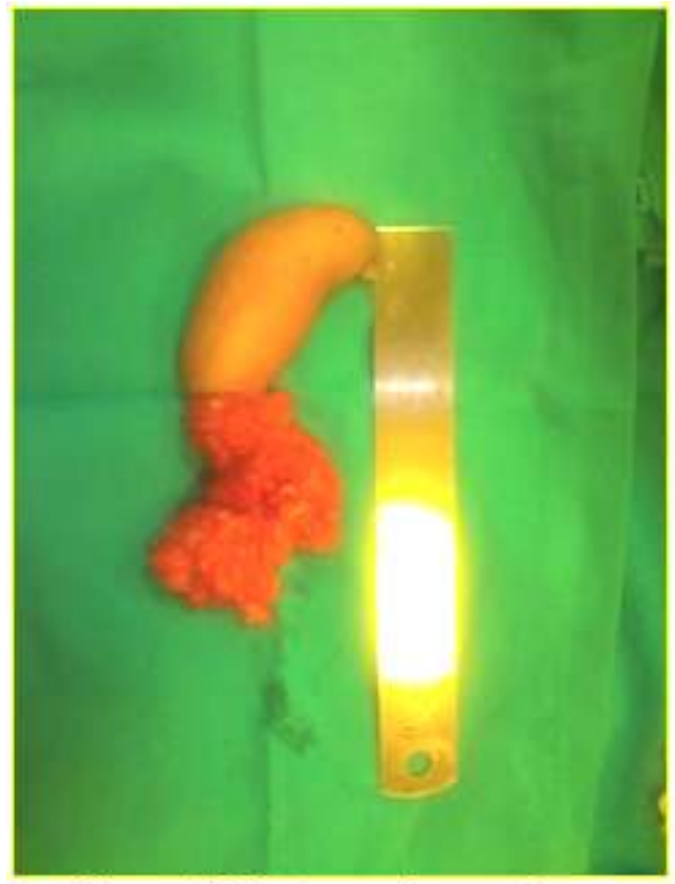

Figure 3: Post-operative specimen

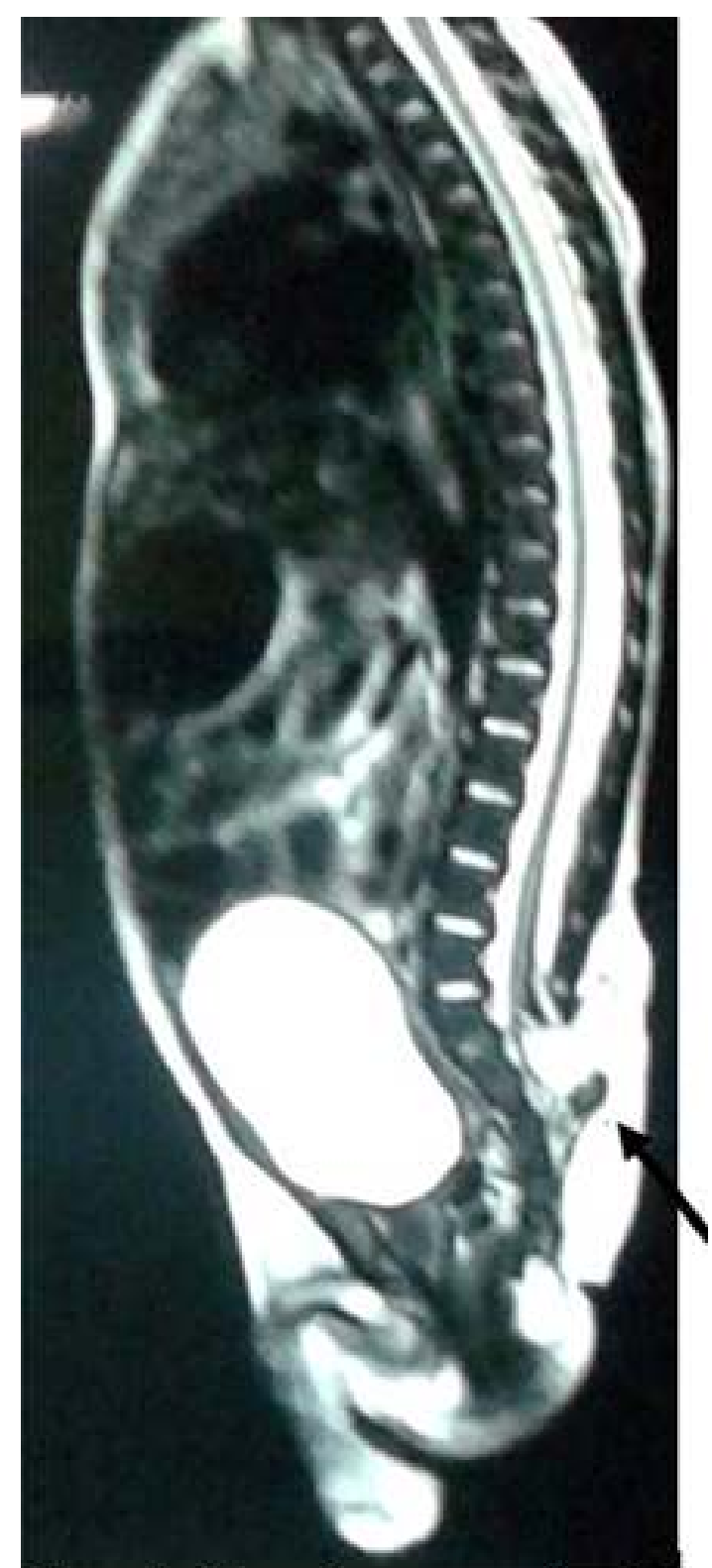

Figure 2: Magnetic resonance imaging of spine showing spina bifida 